\title{
The relationship between poor sleep and inhibitory functions indicated by event-related potentials
}

Markus Breimhorst $\cdot$ Michael Falkenstein •

Anke Marks $\cdot$ Barbara Griefahn

Published online: 2 April 2008

(C) Springer-Verlag 2008

Erratum to: Exp Brain Res (2008)

DOI 10.1007/s00221-008-1333-9

In the published original version of the article, in the list of references the article by Falkenstein, Hoormann, and Hohnsbein (2002) was not cited correct. It is not published in the International Journal of Psychophysiology but in the Journal of Psychophysiology.
The correct reference should read as follows:

Falkenstein M, Hoormann J, Hohnsbein J (2002) Inhibition-related ERP components: variation with modality, age and time-on-task. J Psychophysiol 16:167-175

The online version of the original article can be found under doi: 10.1007/s00221-008-1333-9.

M. Breimhorst · M. Falkenstein · A. Marks · B. Griefahn ( $\square)$ Institute for Occupational Physiology at Dortmund University, Ardeystr. 67, 44139 Dortmund, Germany

e-mail: griefahn@ifado.de

M. Breimhorst

e-mail: markusbreimhorst@gmx.de 